\title{
Maitreya's Garden in the Township: Transnational Religious Spaces of Yiguandao Activists in Urban South Africa
}

\section{Nikolas Broy}

\section{OpenEdition}

\section{Journals}

Electronic version

URL: http://journals.openedition.org/chinaperspectives/9662

DOI: 10.4000/chinaperspectives.9662

ISSN: 1996-4617

\section{Publisher}

Centre d'étude français sur la Chine contemporaine

\section{Printed version}

Date of publication: 1 December 2019

Number of pages: $27-36$

ISSN: 2070-3449

\section{Electronic reference}

Nikolas Broy, "Maitreya's Garden in the Township: Transnational Religious Spaces of Yiguandao Activists in Urban South Africa", China Perspectives [Online], 2019-4 | 2019, Online since 01 December 2020, connection on 01 April 2021. URL: http://journals.openedition.org/chinaperspectives/9662 ; DOI: https://doi.org/10.4000/chinaperspectives.9662 


\section{Maitreya's Garden in the Township: Transnational Religious Spaces of} Yiguandao Activists in Urban South Africa*

ABSTRACT: This paper seeks to explore the spaces created by practitioners of the Taiwanese-Chinese religious movement Yiguandao 一貫道 ("Way of Pervading Unity") in urban South Africa. Drawing on ethnographic data from fieldwork conducted in Johannesburg, Pretoria, and Cape Town in late 2017 as well as on published Yiguandao materials, this contribution analyses how these spaces are created, maintained, and charged with meaning. It investigates the uses of these spaces as well as how and why various actors engage in them. By proposing a preliminary typology that is based on the location, function, and mobility of these spaces, this contribution argues that Yiguandao religious spaces represent more intense arenas of transcultural interaction than most other - and predominantly economic - Chinese spaces in Africa.

KEYWORDS: Taiwanese religions, Chinese religions, South Africa, Yiguandao, Chinese migration, globalisation, religious transnationalism.

\section{Introduction}

$\mathrm{t}$ is clear and chilly when we get up on this November Saturday around 5:30 in the morning. Twenty-seven South Africans and I gather in front of a temple. Located in a garage-like building on a private property on the outskirts of Midrand - a fairly cosmopolitan area of probably close to one hundred thousand inhabitants (The 2011 census records 87,387 registered residents) just north of Johannesburg - the temple would not be recognised as such from the outside. Owned and operated by a Taiwanese businessman turned traditional Chinese doctor, who came to South Africa in 1993, the temple was originally established farther north and closer to Pretoria, and finally relocated to Midrand a couple of years ago. As the 13 women, six men, and eight children gather, we begin to engage in physical exercises to keep us fit for the demanding program that awaits us over the following two days. In my fieldwork diary I will note later that I was quite disappointed that the "morning exercise" recorded in the schedule would turn out to be standard stretching moves, and not qigong or taijiquan as I had expected. Yet, it appears to have awakened everybody, and we feel prepared for the many lectures that we will have to listen to during this religious training camp. Suddenly, Mr. Yang - the temple owner - steps forward and explains certain things that need to be kept in mind for the course of this event. Thus, no meat and alcoholic beverages will be served; all participants are expected to attend and seriously pay attention to all lectures; and finally, all participants have to attend three "prayer sessions" in the morning, noon, and evening. Even though he sometimes uses specific Chinese vocabulary, his entire speech is in English. Accompanied by Mr. Yang and several Taiwanese coreligionists, the 27 men and women - all black South Africans - enter the temple and arrange themselves gender-separated in front of the Chinesestyle altar. Reflecting the traditional Chinese notion of nanzuo nüyou (男左 女右), men stand to the left and women to the right (when viewed from the altar). Now Mr. Yang slowly explains the different rites and gestures that all participants are asked to carry out during the ritual. Step by step, he shows them how to properly fold their hands, do the kowtow, and how to bow in front of a statue of Maitreya Buddha in white porcelain, which is placed carefully on the altar along with four other religious effigies. In the theology of this group, the future Buddha Maitreya already descended to earth about one hundred years ago, an event that initiated the final phase in history before our world will eventually come to an end. The morning ritual proceeds with recurring sets of kneeling, prostrating, and getting up again, each set of which is intended to pay respect to a deity or great leader of the religion. About half an hour later, everybody gathers for a simple vegetarian breakfast consisting of white bread, jam, peanut butter, oats, and bananas. About half an hour later, everyone assembles in the temple building to listen to the first lecture of the day.

\footnotetext{
* I would like to express my gratitude to Romain Dittgen, Gerald Chungu, Sébastien Billioud, and two anonymous reviewers for their very helpful comments and suggestions to an earlier version of this paper. Needless to say, I alone am responsible for any remaining shortcomings.
} 


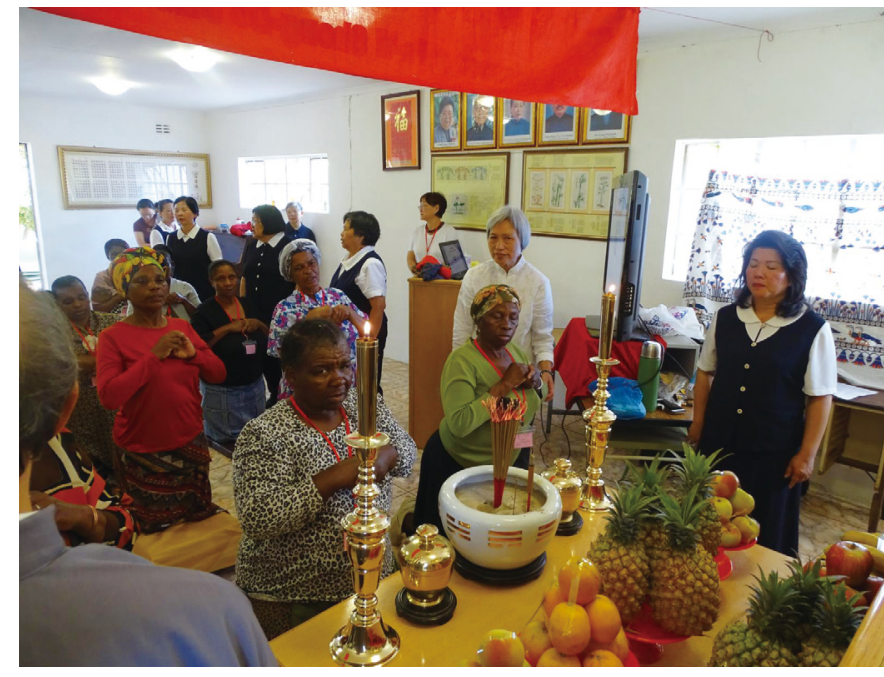

Figure 1. Fayi Chongde Training Camp in Midrand, November 2017. Credit: author

This brief excerpt from my fieldwork diary recalls the first morning of a two-day training camp for neophytes of the Taiwanese new religious movement Yiguandao 一貫道 ("Way of Pervading Unity," official transcription: I-Kuan Tao) that was held in the Johannesburg Metropolitan Municipality area in November 2017. Yiguandao is an enormously popular religious movement in Taiwan that came into being in early twentiethcentury China and exhibits an innovative synthesis of Confucian, Buddhist, and Daoist teachings, as well as sectarian traditions and popular religious influences (Jordan and Overmyer 1986; Lu 2008; Billioud forthcoming). Having spread beyond China and Taiwan since the 1940s, Yiguandao activists have established a presence in more than 80 countries across the globe (Broy, Reinke, and Clart 2017: 20-4). It is currently one of the fastest growing religious movements in Asia and has established firm roots particularly among Chinese communities in Southeast Asia (Soo 1997; Song 1997; Lim 2012). Other parts of the world - such as Europe, the Americas, and Africa remain tremendously understudied (Billioud 2016; Yang 2015). As indicated above, most participants in this training camp were black South Africans, while the leadership and all religious specialists were either local Taiwanese South Africans or invited speakers from Taiwan and Singapore. This meeting was one of many similar events that Yiguandao activists have staged during the past decades to spread their teachings not only among Chinese migrants in South Africa, but also among the local populace. For dedicated Yiguandao practitioners - whom I call "activists" in order to highlight the missionary zeal and sense of eschatological urgency that dominates their entire private and business lives - proselytization is part of a global project of establishing a community of Dao followers across cultural, ethnic, and national boundaries, which they term "Maitreya's garden" (Mile jiayuan 彌勒家園) (ZHHX, \#225, 2010/6: 7). ${ }^{2}$ While the trope of the "garden" or "native place" (jiaxiang 家鄉) has been used in many popular sects in late imperial China to describe the transcendent realm of salvation to which pious believers will eventually repatriate (cf. Seiwert 2003: 368-70 et pass.), Yiguandao activists employ this metaphor to specifically highlight the innerworldly nature of their activism, so as to establish the "Pure Land in the human realm" (renjian jingtu 人間淨土) or "Great Peace on Earth" (shijie datong 世界大同) - to name two other Buddhist and Confucian symbols that frame Yiguandao's salvational project in similar spatial terms.

Despite Yiguandao's fairly long presence in South Africa, dating back to the late 1970s and early 1980s, it has not been the object of academic inquiry before now. Thus, the growing body of research dedicated to Chinese migration focuses primarily on entrepreneurial engagement, such as Chinese shopping malls and wholesale centres (Park and Chen 2009; Park 2012; Huynh, Park, and Chen 2010; Harrison, Moyo and Yang 2012; Deumert and Mabandla 2013; Lin 2014a, 2014b; Dittgen 2015; Xiao 2016), but cultural and religious enterprises have not yet been spotlighted by international scholarship. Apart from one recent MA thesis about Chinese Christian congregations (Grant 2014; Grant and Niemandt 2015) and preliminary findings about the activities of the Taiwanese Buddhist organisation "Buddha's Light Mountain" (Foguangshan 佛光山) (Master Hui Li 1999; Chandler 2004: 262-3, 294-8; Broy, Reinke, and Clart 2017: 19), Chinese religious activities in South Africa remain a tremendously underrepresented field of inquiry (for South African Born Chinese $[S A B C]$ ) - most of whom have turned to Christianity - see Smedley 1978: 62-3; Song 1999; Yap and Man 1996: 398402).

This contribution seeks to enrich the discussion on "ordinary Chinese spaces" by exploring the religious spaces created by Yiguandao activists in urban South Africa, particularly in the Johannesburg and Pretoria region. I shall argue that these spaces represent arenas of transcultural and transnational interaction and accordingly are an integral part not only of Chinese, but also non-Chinese urban realities in contemporary South Africa. Far from being exoticized as the absolute "other" that exists parallel to the host society, Yiguandao temples and activities provide an arena to negotiate matters of belonging, morality, and religious salvation in transcultural and border-crossing patterns. Before delving into the analysis of Yiguandao's religious spaces in South Africa, I will introduce the history of the movement in South Africa in the following section. In the main part of the contribution, I propose a preliminary typology of ordinary religious spaces that is based on the location, function, and mobility of these spaces. First, I will discuss temples situated in (1) shopping malls, (2) factories and business offices, and (3) private residences. Inspired by Thomas Tweed's work on religious spaces as processes (Tweed 2015: 226-7), I add community outreach as (4) kinetic spaces, because Yiguandao's proselytization and charity engagements help to set up particularly fluid and temporary but also meaningful spaces in non-Chinese residential areas. While it is arguably true that charities and missionary work are also staged in stable sites (temples), this type of community outreach represents an inherently mobile pattern as it specifically aims at "seizing" and temporarily transforming "other" spaces into Yiguandao ones. This analytical model follows a heuristic purpose, and it does not claim that these ideal types represent four distinct types of transcultural interaction. The preliminary findings presented here draw from ethnographic fieldwork conducted in Johannesburg, Pretoria, and Cape Town from October to December 2017 as well as from an analysis of published Yiguandao materials. ${ }^{3}$

1. I shall use "Chinese" in a broad understanding to refer to individuals and communities who trace their origins back to Chinese ancestry and share Chinese cultural notions and practices, such as the Chinese language, but without indicating any national identities of individual members of these communities. Instead, I will use "Taiwanese" or "PRC/Mainland Chinese" to further distinguish them.

2. The abbreviation ZHHX refers to Yiguandao zonghui huixun 一貫道總會會訊, the official monthly journal published by the General Association of Yiguandao - a representative body of most Yiguandao branches in Taiwan founded in 1988. The journal is distributed among temples and individual members worldwide and transmits news about recent activities, discussions of religious issues, and news from overseas congregations.

3. This research is part of a larger project on the global spread of Taiwanese religious organisations conducted at the Collaborative Research Centre (SFB) 1199: "Processes of Spatialization under the Global Condition" at Leipzig University, 2016-2019. It is funded with a grant from the German Research Foundation (DFG). For an introduction to this particular project as well as the research centre, see Broy, Reinke, and Clart (2017) or visit https://research.uni-leipzig.de/ sfb1199/about/ sfb-1199/ (accessed on 8 May 2019). 


\section{Yiguandao in South Africa}

The development of Yiguandao in South Africa is closely related to the history of Taiwanese migration to the country. Accordingly, the influx of Taiwanese business migrants from the 1970s to the early 1990s - which is generally considered the first wave of post-1950 Chinese migration (Hart 2002: 165-97; Park and Chen 2009: 26-7; Park 2012; Xiao 2016: 42-63) coincided with the earliest phase of Yiguandao's activism in the country, which appears to have begun around 1979-80 (Fan 1987: 44; Song 1983: 206). One recent account by South African-based members links the founding of the first public temple in Lesotho in 1984 to the entrepreneurial engagement of a Taiwanese business migrant (ZHHX, \#314, 2017/11: 43). The people I encountered during my fieldwork virtually all came to the country in order to pursue business, some of them invited by friends, others taking the chance on their own. While they portray Yiguandao activism as the key incentive in their daily lives, most of them only encountered a turn towards the faith after their arrival in South Africa. Thus, it appears that the diaspora experience in particular has fuelled their turn towards religious faith and practice.

Proselytization follows a general pattern that aims to combine occupational and religious activities, and which can be observed from Yiguandao's early twentieth-century history onward. Unlike full-time employed missionaries who are paid to spread their faith beyond borders, Dao followers consider themselves lay practitioners who of course need to work in order to make a living. Yet, their entrepreneurial impetus is highly valued as a means to "bring the Dao to wherever your work brings you" (shengyi zuo dao na, daowu jiu kai na 生意做到哪, 道務就開哪), as it is phrased in a famous slogan that renders the global spread in economic terms (Lu 2008: 82-3; Skoggard 1996: 169-70). Even though Dao followers are requested to prioritise religious over mundane matters as represented in the famous phrase zhongsheng qingfan (重聖輕凡) in most cases economic itineraries are the primary driving force behind Yiguandao's expansion. Because Yiguandao is not a uniform religious body, but a heterogenous movement composed of various independent branches with sometimes conflicting agendas, it is clear that proselytization often represents rather fragmented efforts. In order to facilitate cross-branch cooperation and thus the scope of missionary endeavours in South Africa, a number of committed followers established an Yiguandao friendship association in 1997, which became the forerunner of the official "Yiguandao General Association of the Republic of South Africa" (Yiguandao Nanfei zonghui 一貫道南非總會) established in Pretoria in September 2011 (ZHHX, \#236, 2011/5; \#240, 2011/9: 4-8; JCZZ, \#275, 2011/11: 10-3). ${ }^{4}$ It is the first and only association of its kind on the entire continent.

Because reliable overall data is missing - which is partly due to the segmentary structure of Yiguandao, but also to the high level of fluidity in terms of actual participation as well as remigration - it is difficult to give exact numbers of temples and regular practitioners. Judging from internal material, estimations rise from 800 Dao followers in the late 1980s (Fan 1987: 44) to tens of thousands as well as 26 temples in the early 2000s (Mu 2002: 225). One of my informants claimed that his branch alone converted more than 30,000 black South Africans during the past two decades, but only about a dozen truly engaged followers were left today. Activists often explain these difficulties in generating long-term commitment in terms of cultural differences between Chinese and Africans, and some even resort to ethno-cultural stereotypes. For instance, a leading member of the Fayi Chongde (發一崇德) branch in Taiwan told me in a personal conversation in 2016 that South African Dao followers were ignorant of Chinese history and Yiguandao teachings; instead, they would only join the group to fill their bellies, but they were almost incapable of understanding the true Dao. Based on my fieldwork experience (which of course is only a temporally and geographically limited snapshot), most congregations are relatively small, ranging from 10 to 30 regular practitioners.

Today, there are basically seven branches active in the country: Baoguang Yushan 寶光玉山 (since 1980s), Baoguang Jiande 寶光建德 (late 1980s), Fayi Chongde 發一崇德 (1992), Fayi Lingyin 發一靈隱 (late 1990s), Fayi Cifagong 發一慈法宮 (early 1990s), Jichu Zhongshu 基礎忠恕 (1990s), and Xingyi 興毅 (late 1980s). It appears that the Johannesburg and Pretoria areas are particularly strong, but there are also minor presences in Bloemfontein, Kimberley, Ladybrand (all three of which are located in or next to the Free State), East London, and Cape Town. Given that Johannesburg and to a slightly lesser extend Pretoria - are important centres of migration and business engagement from both sides of the Taiwan Strait (Harrison, Moyo, and Yang 2012; Chen 2011; Lin 2014b: 33-43), this distribution is hardly surprising. However, several committed activists have returned during the past years to Taiwan or re-emigrated to other countries or safer cities due to recurrent experiences of violent crime and a less favourable economic outlook - another typical pattern in recent Chinese migration in South Africa (Chen 2011: 11; Lin 2014a: 201-3). Local Yiguandao communities enjoy a high level of mutual trust and cooperation with other Taiwanese religious enterprises active in the country, such as Foguangshan, the Tzu Chi Foundation (Ciji gongdehui 慈濟功德會), and the Amitofo Care Centre (ACC, Amituofo guanhuai xiehui 阿彌陀佛關懷協會) established by former Foguangshan Abbot Huili 慧禮法師 in the early 2000s and with many chapters in neighbouring countries (fieldwork data, ZHHX, \#240, 2011/9: 5; \#314, 2017/11: 29-30). ${ }^{5}$

While most committed and high-ranking members seem to be Taiwanese, there is also a considerable cohort of PRC Chinese among the followers. In contrast to the former, who arrived in South Africa during the late 1980s and 1990s and are relatively well-to-do entrepreneurs, most PRC nationals I encountered came to the country only a couple of years ago. Most of them hail from Fujian Province and work as shopkeepers in Chinese shopping malls. Yet again, this development seems to be representative of Chinese migration in general, which has seen a tremendous increase in influx from rural Fujian (Park and Chen 2009: 28-30; Chen 2011; Lin 2014b: 39-40). In addition, I have also found that many local Chinese Dao followers share a history of migration and transnational networking. For instance, one important activist at Jichu Zhongshu branch worked in Japan, Southeast Asia, and the US before coming to South Africa in 1990 (JCZZ, \#103, 1997/7: 41). According to my informants, he has already returned to Taiwan due to his advanced age.

Besides focusing on the Chinese community in the country, Yiguandao has quite a history of outreach to local, non-Chinese South Africans. As far as I can tell from my material and Yiguandao publications, it appears that proselytizing particularly targets the black population. I am not aware of any other Asian or white followers - I know of only one male practitioner of Indian ancestry, but whose participation was prompted by being married to a Taiwanese South African Yiguandao member. Consequently, South African Yiguandao congregations are not only transnational and transcultural communities, but there is also a relatively high degree of fluidity in

4. JCZZ refers to the journal Jichu zazhi 基礎雜誌, which has been published monthly since 1989 as the official mouthpiece of the Jichu Zhongshu 基礎忠恕 branch.

5. On the ACC, see its international website http://www.accngo.org/ (accessed on 8 October 2018). 
terms of who participates in religious activities and who belongs to the congregation. In contrast, in day-to-day business, linguistic communities often operate separated from each other, with relatively little interaction between Chinese- and non-Chinese-speaking congregations as well as between Taiwanese and PRC communities. As will become clear below this observation owes to obvious linguistic reasons (i.e., Chinese-speaking members prefer to participate in a Chinese congregation, while non-Chinesespeaking practitioners would not understand the communications in Chinese communities) and different expectations on the part of different linguistic and cultural groups.

Before delving into the analysis, a last note on the notion of "temples" seems appropriate here. Unlike most "otherworldly" religions that seek respite from the "hustle and bustle" of everyday life, Yiguandao locates its spaces for religious and moral cultivation at the very core of social life. Thus, already in the early history of Yiguandao in China, "Buddha Halls" (fotang 佛堂) were often founded in private residences, shops, or other buildings. The establishment of Buddha halls in sites that modern nation-states have ascribed as "secular" - such as private residences or business premises - is at the heart of Yiguandao's proselytization strategy and demonstrates how its activists are able to circumvent state regulations on public religious usages of spaces (Lim 2012: 30-3). This is due to the fact that Yiguandao theology strongly urges pious followers to erect a Buddha hall in her or his own house - which means setting up an altar and keeping certain behavioural rules of conduct, such as observing a vegetarian diet (which always includes abstaining from alcohol and the "five pungent plants," such as onions, garlic, and leeks), keeping the altar room clean, and conducting regular rites at the altar (three times a day and on special occasions) (Lim 2012: 31-2). Furthermore, the construction of huge temple complexes in the traditional Chinese manner and similar to Buddhist or Daoist estates is a rather recent phenomenon that emerged in the 1970s (Lin 2009: 20-6). But even today, only branch headquarters or large congregations will operate special temple complexes, while the vast majority of Buddha halls are still located in private residences or work places. Consequently, most "temples" are basically rooms or niches dedicated to Yiguandao practice. Accordingly, activists' spatial practices differ from those of other Taiwanese religious organisations that usually establish special-purpose centres. Probably the most instructive case is the huge temple complex Nanhuasi 南華寺 established by Foguangshan near Bronkhorstspruit in 1992. As the largest Buddhist temple on the entire continent and one of Foguangshan's largest edifices outside of Taiwan, the temple is located in a projected business enclave that was intended to attract Taiwanese investments on an unprecedented scale. Even though it operates several local centres, such as the Universal Awakening Buddhist Centre in Johannesburg's "second" Chinatown in Cyrildene just northeast of downtown, most regional chapters seem to particularly target the Chinese community (fieldwork data, cf. Chandler 2004: 294-5). While Yiguandao discourses distinguish between "domestic" (jiating fotang 家庭佛堂) and "public Buddha halls" (gonggong fotang 公共佛堂), the examples discussed below demonstrate that many "public" temples are actually located in private residences, and some "temple masters" (tanzhu 壇主) - those in charge of managing temple affairs - live in public fotang.

\section{Ordinary religious spaces}

\section{Shopping malls}

During the past decades, Johannesburg has been a major centre of Chinese migration and investment in South Africa, which is visible in the existence of several China malls and Chinese wholesale centres. In 2017, there were at least fifteen such institutions located in the western and southwestern part of the metropolitan region alone, with two additional Chinatowns in downtown Johannesburg (the historical one) and Cyrildene (the new one) (Lin 2014b: 33-8; Dittgen 2017: 982). Consequently, it is no wonder that Yiguandao activists direct their efforts particularly at these commercial spaces. One of these is the Chonghui Fotang 崇慧佛堂, which was established in the relatively smaller China Cash \& Carry mall by the Fayi Chongde branch in 2014. Located in Crown Mines in the southwestern part of the metropolitan area, China Cash \& Carry is not only a commercial site, but also provides space accommodating a number of Chinese shopkeepers who often work in adjacent malls (Dittgen 2017: 986). The fotang is basically a shopping booth converted into a special-purpose temple, with an altar and religious artefacts, including a bookshelf with introductory pamphlets and booklets (all in Chinese). The booth has been made available by a well-to-do donor. Despite Yiguandao's strong promotion of vegetarianism, Chonghui Fotang is located next to an Indian Burger restaurant and a Chinese restaurant (that also serves meat) on the opposite side. While the mall itself is rather quiet and does not appear to attract as many consumers as China Mall or Dragon City, for instance, the fotang seems to have been established here on purpose, as China Cash \& Carry houses a large Chinese community, because a significant portion of the entire space is assigned to accommodation on site. Thus, to operate a Yiguandao temple within a major Chinese residential area appears to follow a strategic missionary rationale.

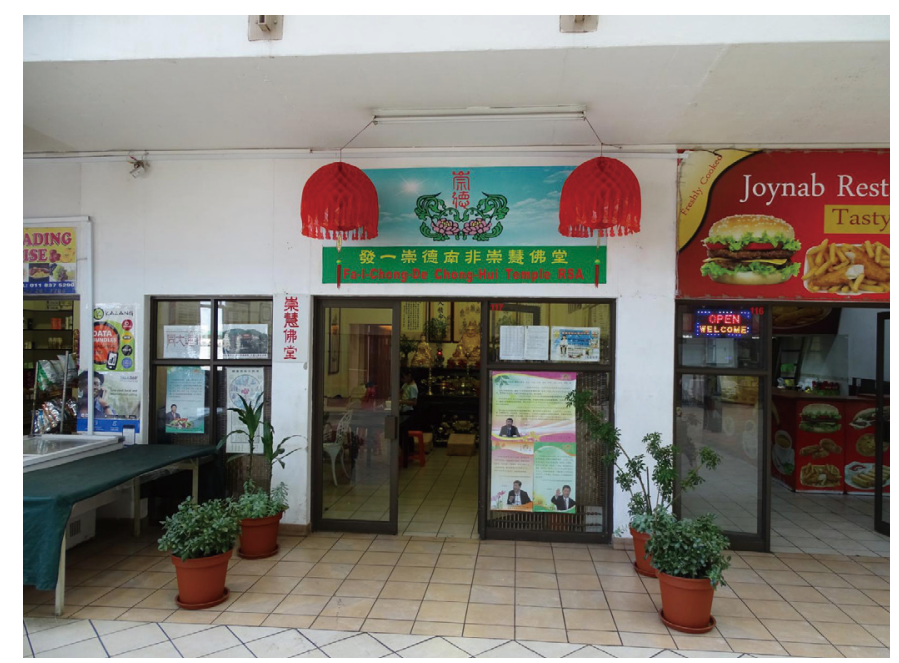

Figure 2. Buddha Hall in China Cash \& Carry, November 2017. Credit: author.

Because the shopkeepers - most of whom hail from Fujian Province - are eager to make money and therefore will keep their stores open 24/7, the temple is usually closed weekdays and will open only for regular training classes on Saturday evenings and Sunday mornings. Similar observations have been made among some Chinese Christian churches in Johannesburg that are also forced to offer religious services in the late evening to attract Fujianese people (Lin 2014b: 41-2). The PRC provenance of most local members is clearly visible on the outside window of the temple, where several posters depict President Xi Jinping and his quotations about how traditional Chinese values help to foster the moral quality (daode suzhi 道 德素質) of the people. These posters were issued by Fujianese associations active in South Africa. Besides the largely Fujianese following, the leading personnel appear to be entirely Taiwanese. These people who oversaw managing the temple and its activities severely criticised the Mainlanders' 
alleged rationale of prioritising commercial over religious commitment. The religious weekend of the Chonghui Fotang begins with a "research class" (yanjiuban 研究班) - an advanced course for Dao followers in Fayi Chongde's curriculum - to be held on Saturday evening. On Sunday morning, there is a "classics reading class" (dujingban 讀經班) for children. When I visited the temple, there were five to seven kids training to memorise chapters of the Daodejing and the Analects. Right before the class, the children sang the Classic of the One Hundred Occurrences of Filial Piety (Baixiaojing 百孝經) - an enormously popular Fayi Chongde text about the Confucian norm of filial duty - and then bowed three times before a painting of Confucius. In other sessions, the kids prepared excerpts from the Zhuzi zhijia geyan 朱子治家格言, a seventeenth-century didactic work that also enjoys great popularity among traditionally-minded circles in contemporary mainland China. Even though most studies on recent Chinese migration found a gap between the longer-residing Taiwanese migrants and their recent counterparts from Fujian - usually less educated and with fewer economic resources (Park 2012; Harrison, Moyo, and Yang 2012: 910-1; Lin 2014b: $39-40,48-9)$ - the Chonghui congregation shows a distinctive and regular pattern of interaction between both groups that seems to centre on shared notions about Chineseness; namely a focus on Confucianism, individual and public morality, and traditional Chinese values (e.g., paying respect to parents and elders, propriety, etc.).

Another example is the Tongyuan Fotang 同圓佛堂, which is based in Johannesburg's China Mall West located in Industria and next to national route one. Operated by a traditional Chinese doctor in his early forties, who migrated to South Africa from Fujian in 1996 and also runs his own business of importing and reselling Chinese medical products, the temple is located within his Chinese health care centre. After being relocated four times, it has been at its present location since late 2016. Similar to China Cash \& Carry, China Mall West is a rather quiet and unprosperous shopping centre. Yet, the doctor's deliberate choice to locate his business and his temple here owes to its relative proximity to suburban residential areas, such as Soweto, where many of his patients, but also followers come from. The temple offers regular introductory courses (in Fayi Chongde's system called mingdeban 明 德班) that are usually held on Sunday morning from 9 to 12. In contrast to the temple discussed above, all participants are local black South Africans, most of whom live in Soweto, only 15 kilometres away. When I participated in the classes, there were about 13 regular participants, about two-thirds of whom were women, and even several children. The Chinese and Taiwanese teachers would lecture about the short poem "The Objectives of Dao" (Dao zhi zongzhi 道之宗旨), which is displayed in virtually all Chongde Buddha halls. Taken from the influential introductory booklet Explaining Topics concerning the Nature and Principle (Xingli tishi 性理題釋), the text teaches conservative moral values as well as the concept of cause and effect (karma), but the teachers also elaborate on how hard work and remaining diligent in one's pursuits would enable anybody to manage her or his life.

Several members of this congregation were attracted to Yiguandao through the healthcare centre and the doctor's enthusiasm in providing medical aid for free on a monthly basis. Because many of them experienced improvement in their diseases - particularly diabetes - they appear very emotional and committed. Based in Snake Park in Soweto, this cohort is less well-off, and most of them work in local small-scale businesses. This intense interaction with the temple head appears to have channelled quite a commitment among several regular participants: while some would always assist in preparing food for the communal dinner, others are devout

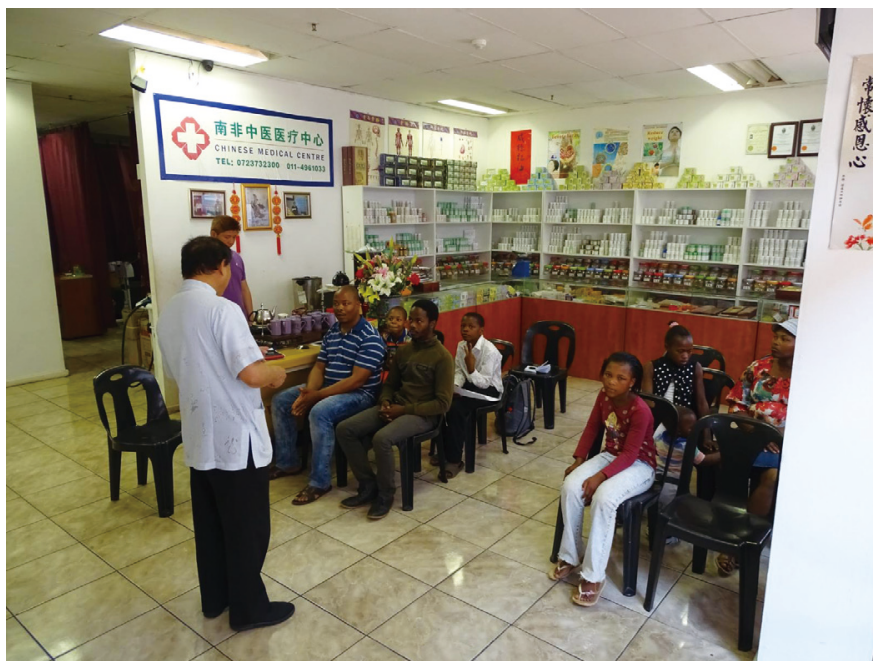

Figure 3. Weekly meeting in Tongyuan Fotang, China Mall West, November 2017. Credit: author.

and attentive listeners. Basically, the Snake Park cohort seems to be deeply religious and faithful followers, and virtually all of them were already Christian believers before they joined the group. Most of them continue to regularly attend church services and consider themselves Christians an observation that fits Yiguandao's self-understanding as encompassing various religious beliefs and practices. The other, smaller cohort is comprised of eclectic religious seekers, who appear to be relatively well-to-do and are unified by their interest in kung-fu, yoga, and Eastern spirituality - as the doctor is also a trained master of Shaolin kung-fu. One of them became involved after having read Chia Mantak's 謝明德 (b. 1944) bestsellers about yoga, qigong, and Dao practice. The spiritual teacher from Thailand has developed his own spiritual system that seeks to integrate yoga, qigong, and Daoist philosophy and has a particularly strong following among spiritual seekers in the US (Palmer and Siegler 2017:68-73). This case is truly instructive in how the diffusion of Asian spirituality and bodily practices to South Africa have fostered an ecology of understanding and familiarity that Yiguandao activists can take advantage of. Diffusion refers here to the import of more or less disparate cultural elements into other societies through books, movies, TV programs, and other media. Thus, diffusion plays an important role in fostering a favourable ecology that is receptive to the imported religion (Finney 1991: 393-4). Another fairly young member of this congregation felt truly "awakened" after having led a life of crime and drug-addiction in his youth. For him, Dao and the moral values taught by Yiguandao (filial duty, being hardworking and diligent, self-restraint, temperance) are a new compass in life that he and others feel is missing in South Africa.

\section{Factories and business offices}

As one would expect, the greater Johannesburg region is also home to most Chinese firms and factories. Judging from an imperfect analysis of the "Companies and Intellectual Property Commission" database, Harrison et al. have found that more than half of the 329 Chinese enterprises recorded there are situated in Johannesburg, with an additional 15\% in Pretoria and only 12\% in Cape Town and 7\% in Durban (Harrison, Moyo, and Yang 2012: 912-5). As far as I can tell from my material, it appears that particularly in the early phase of Yiguandao's spread to South Africa - which coincided with the economically strong period of Taiwanese investment and factorybuilding (Hart 2002: 165-97; Park and Chen 2009: 27-8) - many activists established altar spaces in their factories or office rooms. In this section, I 
discuss the example of the Baoguang Jiande branch, which appears to have been especially eager to engage in this pattern of temple-building. Several journal articles recall how during the 1990s pioneer activists made spaces available to erect "temporary Buddha halls" (linshi fotang 臨時佛堂) in their factories to convert their black employees (cf. JCZZ, \#233, 2008/5: 32; \#236, 2008/8: 42).

During my fieldwork I encountered a committed Taiwanese couple who came to South Africa back in 1988. After running several businesses, they currently operate a retail shop that sells garden furniture, plants, and flowers on the outskirts of Pretoria. They also use the estate to grow their own vegetables, including delicious bamboo shoots that they provide to other Buddha halls as well. Inside the office, there is a small altar space that also displays the name of the fotang, which is "Great Ancestor Temple" (Dazutang 大祖堂) - to indicate that this temple is the first public Buddha hall, originally founded by the Baoguang Jiande branch in 1992 in the northeastern suburbs of Pretoria. Today, almost the entire family is involved in the religious enterprise: One son and one daughter live in Pretoria, and another son lives in suburban Cape Town and also runs a private fotang in his house. Besides having a larger special-purpose temple (the Tiantai bentang 天泰本堂) outside of Pretoria, the Dazutang has helped them to initiate all employees into Yiguandao. For them, the Chinese-style altar is part of their work space. One of their female employees was even able to speak perfect Mandarin and prepare authentic Taiwanese vegetarian food during my visit.

\section{Private residences and special-purpose temples}

As most SABCs and relatively well-to-do Chinese migrants left the city centres of Johannesburg and Pretoria in the course of increasing innercity crime since the 1990s (cf. Harrison, Moyo, and Yang 2012: 917-8), many established Taiwanese Yiguandao activists chose to settle in the safer suburban regions of these two capitals. In this section I will discuss the Tongde Fotang 同德佛堂 located in Midrand, which is the Buddha hall that I introduced in the opening paragraph of this contribution. Originally established in 1995 in Pretoria, the fotang followed temple owner Mr. Yang and his family during various relocations to Centurion (another area in the southwestern part of Pretoria) and finally to Midrand a couple of years ago. As described in the introduction, the temple is situated in a garage, which is part of Mr.Yang's large estate, which also houses his own residence, a cottage for the gardener, a small pond, and a two-meter statue of Bodhisattva Guanyin. In addition to the Buddha hall itself, Mr. Yang's house also provides a small library and rooms that are available for guests (such as the visiting masters and lecturers during the training camp).

It is very clear that there exist no clear-cut boundaries between $\mathrm{Mr}$. Yang's private spaces and the Buddha hall. For instance, the helpers and cooks - who were primarily Taiwanese and to a lesser extend PRC Chinese devotees from South Africa and abroad - would naturally use his lounge room and kitchen during the training camp. This is also obvious from his selfunderstanding: thus, unlike other Buddha halls that are situated in private residences, Tongde temple is designated as "public" (gonggong 公共). Apart from the large statue of Guanyin, however, the "Chineseness" becomes visible only from within the temple with its religious symbols, Chinese books, and paintings on the wall. Yet, the temple interior is also clearly intended to construct a cross-cultural identity. For instance, there are Chinesestyle paintings depicting each founder of "The Five Great Religions," i.e., Confucianism, Daoism, Buddhism, Christianity, and Islam. Similarly, another traditional Chinese painting depicts the final moment of salvation (which is termed longhuahui 龍華會, "dragon flower assembly") in heaven. Here, the Eternal Mother (Wusheng Laomu 無生老母) - omnipotent creator of the universe and supreme God in Yiguandao's pantheon - is accompanied not only by Confucius, Laozi, Buddha, and other Chinese saints and cultural heroes, but also by Jesus Christ, Mohammad, and Virgin Mary. Even though Yiguandao spirit revelations have proposed the idea of the unity of the Five Teachings at least since the late 1930s (Clart 2007: 1320-30), depictions of Christian and Muslim symbols are rare in Taiwanese Yiguandao temples. In this case, Mr. Yang appears to be very sensible in applying Christian symbols and language (see below) to spread the Dao to locals, who usually have a Christian background.

The two-day training camp for neophytes, which I described in the introduction, is entitled "class for improvement in cultivation and refining one's nature" (shuaixing jinxiuban 率性進修班), but colloquially it is most often referred to as fahui 法會 ("Dharma assembly"). The event was nominally led by three initiation masters (dianchuanshi 點傳師 - a highranking member assigned by branch elders with the task of conversion), two of whom were from Taiwan, and another from Singapore. Besides local Taiwanese and PRC Chinese assistants, additional helpers also came from Taiwan and Singapore, and there was one Taiwanese Yiguandao family that travelled from East London specifically to support the event. While some presenters lectured in English, other talks were translated by Mr. Yang or others. Between most sessions, the participants would sing various Yiguandao songs - either translated or specifically written in English - such as "Dear Teacher," which is dedicated to the supreme eighteenth patriarch Zhang Tianran 張天然 (1889-1947). ${ }^{6}$

The training camp aims to transmit basic teachings and rituals, the last of which are often experienced by the participants themselves in real practice sessions. Even though the black South African neophytes were not able to speak or read any Chinese, several Taiwanese lecturers would still revert to the well-established discursive strategy of glyphomancy - i.e., to persuade listeners by exploring secret truths allegedly hidden in Chinese characters (Irons 2000: 183-4). Still, most non-Chinese participants were truly impressed by these practices. Equally typical of such an event, the neophytes were encouraged to make vows at the end of the camp. Thus, they were asked to prioritise "holy affairs" over "ordinary ones" (emic translation of the standard Yiguandao term zhongsheng qingfan 重聖輕凡) and to "spread the Cospel" by making financial and other contributions (caifa shuangshi 財法 雙施). The mechanism of making and fulfilling vows is generally regarded as an important key to Yiguandao's success in producing commitment, as it provides compasses and maps for individual spiritual itineraries (Lu 2008: 71-90). At the very end of the training camp, all initiates received a small introductory booklet entitled Holy Assembly of Tao and a souvenir that one of the transmission masters brought from Singapore as well as cookies, fruits, and a vegetarian lunchbox to take back home - as for Yiguandao activists it is very important to refrain entirely from meat on such an auspicious day. The concluding greeting of the main transmission master "May you all be lucky" (zhufu dajia 祝福大家) was translated by Mr. Yang as "Bless everyone, God bless you." As can be gleaned from this brief description, the training camp provided a multifaceted arena to familiarise newcomers with Yiguandao teachings and practices, but it equally gave the opportunity for the largely Christian believers to experience Yiguandao with a Christian appearance. 6. Cf. an identical version of the song uploaded on Youtube: https://youtu.be/J3pdnrMdzPU (accessed
on 9 October 2018). 


\section{Kinetic spaces: Black community outreach}

As the aforementioned examples have demonstrated, temples have a history and they change in terms of extension and duration (Tweed 2015: 226); yet, they are relatively stable - at least for a certain period of time. On the other hand, Yiguandao activists also stage regular events far away from their temples and residences, and often in different places. The most instructive example is Baoguang Jiande branch, whose members engage in various charities and similar events, such as regular winter relief, donating food and clothes, running an orphanage, providing volunteer medical aid teams, and providing scholarships for schools and universities (fieldwork data, ZHHX, \#314, 2017/11: 30-1, 44). Most of their engagements are situated in the larger Pretoria area. The heads of Fayi Chongde's Tongde and Tongyuan temples - who are licensed traditional Chinese doctors also follow this pattern. For several years already, they have offered free medical aid to inhabitants of Snake Park in Soweto (just 15 kilometres from Tongyuan temple). Several participants of the two-day training camp I spoke to were from Snake Park, and they were attracted to Yiguandao by the doctors' talent at combining medical aid and religious proselytization.

Similarly, Jichu Zhongshu branch has also witnessed multiple outreaches, most of which were related to the ministry of an extraordinarily dedicated temple leader (ZHHX, \#238, 2011/7: 24-8). Unfortunately, he has returned to Taiwan due to his advanced age, but from what I learned from my informants and other materials, he was an unusually gifted and unwavering activist. From the 1990s until a few years ago, he would mobilise local Chinese followers as well as helpers from Taiwan to provide proselytization classes in townships and suburbs of Pretoria, such as Mabopane, Madidi, Winterveld, and Mamelodi (JCZZ, \#275, 2011/11: 14-5). Similar to the Buddha halls in factories and offices, he would first establish a "temporary temple" in private residences. This inscription of a specifically religious space is particularly important for Yiguandao activists, as initiation rituals and classes are to be held within the confines of a consecrated Buddha hall only. Even though these mobile activists often faced serious language barriers, the aforementioned activist was able to gather a number of local "talents" the way Dao practitioners address extraordinarily talented members (rencai 人才 in Chinese) - who are long-term members and regular participants, and who are able to mediate and translate. One of them is Isaac, who was initiated into Jichu Zhongshu branch in 1994 in Pretoria, and who ever since has been working to spread the faith in black residential areas, building on a familiarity with language and local culture that most Taiwanese-born activists would never achieve (JCZZ, \#97, 1997/1: 50; \#221, 2007/5: 15; \#238, 2008/10: 39; \#251, 2009/11: 32-3; \#298, 2013/10: 24-5). Similarly, during my fieldwork I also encountered one local practitioner who serves as "intercultural mediator" between the Chinese and Taiwanese activists on the one hand and the black neophytes on the other. Not only are they able to broker interactions between the two groups, but they also serve as "gatekeepers" deciding who is in and who is not (Schubert 2012: 209, 216). They also serve as spatial bridges between cohorts of black South Africans and the Chinese community, who tend to reside in different areas based on their socio-economic differences. In other cases, Chinese Yiguandao activists themselves function as gatekeepers and bridges, as they are deeply engaged in transcultural interactions because of their economic professions, such as factory bosses or traditional Chinese doctors.

Luckily, several volunteers who visited from Taiwan to support local activists in their religious outreach have published reports about their experiences in the jichu Zhongshu monthly journal. For instance, in late 2006 a group of activists travelled to remote villages to initiate interested residents into the Dao, to hold classes, and introduce basic teachings (often through collectively singing Yiguandao songs). Likewise, they were accompanied by two senior black South African members - namely Isaac and his sister. For such endeavours, the master in charge would rent a car to take all the items they would need with them, such as whiteboards, texts, and prayer cushions (baidian 拜熱), but also food and drinks (JCZZ, \#221, 2007/5: 12-19; \#222, 2007/6: 32-33). Sometimes more than one hundred people are said to have participated in the events (JCZZ, \#97, 1997/1: 4851). Other volunteers report similar experiences: after attending lectures in the morning, all participants experience ritual practices in the afternoon often by simple imitation. In addition, they sometimes sing Yiguandao songs in Chinese by using Pinyin romanisation (JCZZ, \#237, 2008/9: 46). Some Taiwanese observers report that they actually felt embarrassed at how some South African practitioners were able to memorise the entire Three Character Classic (Sanzijing 三字經) - another didactic text particularly for young children - thus demonstrating an effort greater than their own, as Chinese is not their native language (JCZZ \#231, 2008/3: 24). In training camps similar to the one describe above, participants also fill out "pledge cards" (xuyuanka 許願卡), such as "At home: I will help my mom to do housework; At school: I will listen to teachers and love my friends; At [the] temple: I will bring my family and friends to the temple to receive Tao" (JCZZ, \#237, 2008/9: 4447; \#238, 2008/10, 36-40; the quotation is from \#238, 2008/10: 37). Due to the language barrier, many sessions turn into multi-language events: while the master talks in Chinese, local talents (Chinese or black South African) translate into English and/or local languages, such as Zulu or Xhosa.

\section{The spatial layout of Yiguandao's engagements}

Unlike Taiwan, even public temples usually operate only outside of office hours (i.e., on weekends) and many are closed to outsiders. Furthermore, most sites are not located in the city centres, but mainly in more welloff suburban residential areas, shopping malls, and Taiwanese-owned factories. Thus, despite the high levels of individual religious zeal, many Yiguandao spaces tend to be hidden or even invisible to most outsiders. This concealment is also socially enacted, as neophytes usually need to be introduced into the group by an insider. While this holds true for most Yiguandao recruitment strategies, it is particularly evident in the case of South Africa, where there is no public proselytizing - except for a few regular charitable engagements. There are several reasons for this spatial layout: the first is related to what the sociologist Marian Burchardt (2017: 79-81) has called "urban risks," - i.e., the insecurities posed by high levels of crime as well as social and ethnic segregation. Unlike Pentecostal churches, which, according to Burchardt, aim at protecting people from these risks, Yiguandao activists tend to avoid these spaces of insecurity altogether. Thus, virtually all Taiwanese and Chinese informants stated that they have not been in downtown Johannesburg or Pretoria - which they deem the crime hotspots of Gauteng Province - for years or even decades. It is therefore no wonder that their religious enterprises are likewise situated in safer environments and specifically in places with a higher density of Chinese, i.e., shopping malls and Taiwanese-owned factories. Secondly, because they are often located far away from lower-income black South African residential areas, Yiguandao fotang tend to be remote and difficult to reach for the majority of black practitioners, many of whom tend to have a lower socioeconomic status. Thus, for the two-day training camp Mr. Yang specifically rented a small bus to convey the Snake Park cohort to his temple in Midrand, which is about 48 kilometres further north. With a public transportation system that, except for 
the comparatively expensive Gautrain, is deemed unreliable and dangerous by most informants (both Chinese and black South African), itineraries of this kind would be virtually impossible for these followers. This is also one of the reasons why relatively well-to-do Taiwanese activists prefer to go to the townships and villages themselves and to establish temporary Buddha halls, because they have the resources to be mobile. While there also has been effort to counter these spatial obstacles by establishing temples in black residential areas - such as Baoguang Jiande's Tiantai bentang 天泰本堂, which is located in Madidi (in the northern outskirts of Pretoria) - these engagements have met with little success, as apart from a few regular events they tend to be almost deserted due to the perceived (and real) insecurity in this area.

In addition to remoteness and a higher level of invisibility, South African fotang also tend to have a higher level of mobility than in Taiwan. Thus, corresponding to the changing socioeconomic situation and the meandering fortunes of pursuing business in certain areas during the past decades, many Buddha halls followed the economic-related mobilities of their predominantly Taiwanese "temple masters" (tanzhu). For example, while originally established as a private shrine in his Pretoria home in 1994, Mr. Yang's fotang followed his economic enterprises to Centurion and finally to its current location in Midrand. Likewise, another Buddha hall belonging to the Baoguang Jiande branch was originally founded in Xinzhu, Taiwan, and brought to Sinoville (northern Pretoria), until it was adopted by the former temple master's son and taken to his new home in Parklands (north of Cape Town), where he works as a tourist guide.

Still, despite the remoteness and relatively hidden nature of Yiguandao religious spaces - which is directly related to the urban risks as well as social and ethnic segregation in the country - Taiwanese Yiguandao activists are able to invest their business and charitable ties as well as local "gatekeepers" in recruiting black South Africans and thus make these spaces visible and meaningful for them. Even though the number of regular and committed converts is not as high as many activists have hoped, there exist at least small groups of people who integrate these religious spaces into their own circuits of interaction. Similar practices of simultaneous closure and interaction of Chinese spaces in Africa have been observed among Chinese economic activities (Dittgen 2015), but I contend that Yiguandao's religious spaces are more intense arenas of transcultural interaction. Thus, black South African practitioners need to invest a larger amount of individual resources and attention than - let's say - shopping at a Chinese-run mall. Even though personal interaction may be confined to class and ritual meetings at the temple and thus two to three hours a week, South African followers also take the time to read, practice, and share Yiguandao-related topics at home. Consequently, their religious engagements in fact helps to "ordinarize" these spaces, as the practitioners not only regularly cross their boundaries but also "dwell" in them - to adopt Thomas Tweed's trope of inhabiting spaces (2006: 81-2).

\section{Conclusion}

This contribution has explored four modes of space-making in Yiguandao's religious engagements in South Africa. Based in (1) shopping malls, (2) factories and business offices, (3) private residences, and (4) community outreach activities, this case study reveals distinctive patterns of religious interaction that are characteristic of Yiguandao's growth in general: namely the intersection of economic, private, and religious spaces. Diverging from earlier experiences in China and Taiwan, however, the intrinsically transcultural and transnational religious spaces of Yiguandao Buddha halls try hard to become an integral part of non-Chinese urban life in contemporary South Africa. Even though Yiguandao's teachings, practices, and symbols may appear strange for most non-Chinese practitioners at first sight, activists make a great effort to familiarise them by providing spaces to learn, question, imitate, and appropriate teachings and practices. For some, familiarisation is facilitated because similar cultural products - such as Eastern spirituality, qigong, traditional Chinese medicine - already have been diffused into South African society through books, movies, TV programs, and other media. For others, Yiguandao's constant borrowing of Christian terminology - such as the Cospel, the Grace of God, morning and evening prayers - helps to make its teachings intelligible and meaningful, and to mitigate tension as a nonChristian religion in a largely Christian environment (Billioud forthcoming). Accordingly, the religious spaces of Yiguandao's activism in South Africa are distinct examples of cross-cultural engagement and interaction. When compared to Chinese shopping malls and other spaces of economic activity, Buddha halls comprise relatively high levels of interaction, up to the point of creating friendships and long-lasting relationships between Chinese and non-Chinese Yiguandao members. Yet, the transcultural spaces of interaction have some limitations: unlike communication among Chinese community members who frequently use Line (predominantly Taiwanese) and Wechat (predominantly PRC migrants) apps for exchanges, interaction between Chinese and black South African members is primarily confined to class hours. Most probably due to the lack of financial resources of many black congregation members, there are hardly any online interactions - unlike, for instance, in the United States, where most temples run Chinese and Englishlanguage websites.

Unlike Chinese shopping malls, Chinatowns, and even other Taiwanese religious enterprises (e.g., Foguangshan), Yiguandao's engagements are not confined to enclave-like spaces that help to perpetuate the exotic image of Chinese spaces in Africa. Rather, Yiguandao followers powerfully pursue their project of building a long-lasting transcultural community, which they term "Maitreya's garden." Likewise, during the training camp Mr. Yang frequently addressed the 27 South Africans as part of one big Chongde family (thus, specifically referring to the Fayi Chongde branch). Inspired by Thomas Tweed's argument that religions "propel adherents back and forth between the close and the distant" (2006: 158), one could argue that the religious spaces produced by Yiguandao activists in South Africa constantly move local non-Chinese participants between what is familiar (e.g., Christian terminology and tropes) and what is distant (Yiguandao teachings and practices). Accordingly, the participation of so many non-Chinese actors, vocabulary, and practices puts us in a position of questioning whether these spaces are strictly "Chinese" anymore. To what extend are religious spaces inhabited by actors with various national, ethnic, and cultural backgrounds still bound to the specific ethnic or cultural references that these spaces were originally created in? When do they become transcultural or even global? As this contribution has highlighted, local black South African Dao followers employ specific Chinese symbols, practices, and even language, but obviously they do not identify themselves as "Chinese" - which is a standard approach to defining Chineseness in a global setting (Cohen 1993: 557).

\section{Dr. Nikolas Broy is postdoctoral researcher, East Asia Department / Collaborative Research Centre (SFB) 1199: "Processes of Spatialization under the Global Condition," Leipzig University (nikolas.broy@uni- leipzig.de).}

Manuscript received on 8 January 2019. Accepted on 29 April 2019. 


\section{References}

BILLIOUD, Sébastien. 2016. "De Taïwan à Maison-Alfort, réflexions sur la globalisation du Yiguandao" (From Taiwan to Maison-Alfort, thinking on the globalisation of Yiguandao). La Religion des Chinois en France, Colloque international, Paris, 18 May 2016.

BILLIOUD, Sébastien. forthcoming. Reclaiming the Wilderness. Contemporary Dynamics of the Yiguandao. Book manuscript submitted to Oxford University Press.

BROY, Nikolas, Jens REINKE, and Philip CLART. 2017. "Migrating Buddhas and Clobal Confucianism: The Transnational Space Making of Taiwanese Religious Organizations." Working Paper Series des SFB 1199 an der Universität Leipzig (4): 1-36. https://research.uni-leipzig.de/ sfb1199/ publication/migrating-buddhas-and-global-confucianism/ (accessed on 10 October 2018).

BURCHARDT, Marian. 2017. "Pentecostal Productions of Locality: Urban Risks and Spiritual Protection in Cape Town." In David Garbin and Anna Strhan (eds.), Religion and the Global City. New York: Bloomsbury Academic. 78-94.

CHANDLER, Stuart. 2004. Establishing a Pure Land on Earth: The Foguang Buddhist Perspective on Modernization and Globalization. Honolulu: University of Hawai'i Press.

CHEN, Fenglan 陳鳳蘭. 2011. "Chinatown in Johannesburg: A Social Survey." The China Monitor 61(April): 8-11.

CLART, Philip. 2007. "Jesus in Chinese Popular Sects." In Roman Malek (ed.), The Chinese Face of Jesus Christ. Nettetal: Steyler. 1315-33.

COHEN, Paul A. 1993. "Cultural China: Some Definitional Issues." Philosophy East and West 43(3): 557-63.

DEUMERT, Ana, and Nkululeko MABANDLA. 2013. "'Every Day a New Shop Pops Up': South Africa's 'New' Chinese Diaspora and the Multilingual Transformation of Rural Towns." English Today 29(1): 44-52.

DITTGEN, Romain. 2015. "Of Other Spaces? Hybrid Forms of Chinese Engagement in Sub-Saharan Africa." Journal of Current Chinese Affairs 44(1): 43-73.

DITTCEN, Romain. 2017. "Features of Modernity, Development and 'Orientalism': Reading Johannesburg through its 'Chinese' Urban Spaces." Journal of Southern African Studies 43(5): 979-96.

FAN, Kaiyin 訤開印. 1987. 一貫道的艱辛歷程 (Yiguandao de jianxin lichen, The Arduous Journey of Yiguandao). Xindian: Zhengyi shanshu chubanshe.

FINNEY, Henry C. 1991. "American Zen's «Japan Connection»: A Critical Case Study of Zen Buddhism's Diffusion to the West." Sociological Analysis 52(4): 379-96.

GRANT, Stephen Robert. 2014. "A Missiological Perspective on a South African Chinese House Church in the Light of Alan Hirsch's Six Elements of 'Apostolic Genius'." MA thesis, University of Pretoria.

GRANT, Stephen R., and Cornelius J. P. NIEMANDT. 2015. "The Chinese House Church Movement in South Africa." Koers - Bulletin for Christian Scholarship 80(2): 1-6.
HARRISON, Philip, Khangelani MOYO, and Yan YANG. 2012. "Strategy and Tactics: Chinese Immigrants and Diasporic Spaces in Johannesburg, South Africa." Journal of Southern African Studies 38(4): 899-925.

HART, Gillian. 2002. Disabling Globalization: Places of Power in PostApartheid South Africa. Berkeley: University of California Press.

HUYNH, Tu T., Yoon J. PARK, and Anna Y. CHEN. 2010. "Faces of China: New Chinese Migrants in South Africa, 1980s to Present." African and Asian Studies 9(3): 286-306.

IRONS, Edward A. 2000. "Tian Dao: The Net of Ideology in a Chinese Religion." PhD dissertation, Graduate Theological Union, University of California, Berkeley.

Jichu zazhi 基礎雜誌 (JCZZ) (Foundation Monthly). Taipei: Caituan faren jichu daode wenhua jiaoyu jijinhui. 1989-Present.

JORDAN, David K., and Daniel L. OVERMYER. 1986. The Flying Phoenix: Aspects of Chinese Sectarianism in Taiwan. Princeton: Princeton University Press.

LIM, Francis K. G. 2012. "The Eternal Mother and the State: Circumventing Religious Management in Singapore." Asian Studies Review 36(1): 19-37.

LIN, Edwin K. 2014a. "'Big Fish in a Small Pond': Chinese Migrant Shopkeepers in South Africa." International Migration Review 48(1): 181215.

LIN, Edwin K. 2014b. "Small Pond Migration: Chinese Migrant Shopkeepers in South Africa." PhD dissertation, University of California, Berkeley.

LIN, Rongze 林榮澤. 2009. “戰後大陸來台宗教的在地化與全球 化一以一貫道為例." (Zhanhou Dalu lai Tai zongjiao de zaidihua yu quanqiuhua: yi Yiguandao wei li, Localisation and Globalisation of Chinese Religions in Taiwan after the War - Taking Yiguandao as an Example). Xin shiji zongjiao yanjiu 新世紀宗教研究 7(3): 1-47.

LU, Yunfeng. 2008. The Transformation of Yiguan Dao in Taiwan: Adapting to a Changing Religious Economy. Lanham, MD: Lexington Books.

Master HUI LI. 1999. "Fo Kuang Shan in Africa: Heritage and Future Plans." In Michel Clasquin and J. S. Krüger (eds.), Buddhism and Africa. Pretoria: University of South Africa, Unisa Press. 55-66.

MU, Yu 慕禹. 2002. 一貫道概要 (Yiguandao gaiyao, An Outline of Yiguandao). Tainan:Tianju shuju.

PALMER, David A., and Elijah SIEGLER. 2017. Dream Trippers: Global Daoism and the Predicament of Modern Spirituality. Chicago: The University of Chicago Press.

PARK, Yoon J. 2012. "Living In Between: The Chinese in South Africa." Migration Policy. https://www.migrationpolicy.org/article/living-betweenchinese-south-africa/ (accessed on 3 October 2018).

PARK, Yoon J., and Anna Y. CHEN. 2009. "Recent Chinese Migrants in small Towns of Post-apartheid South Africa." Revue européenne des migrations internationales 25(1): 25-44.

SCHUBERT, Nelly C. 2012. "'Gatekeeper' und 'Broker' als Schnittstellen zwischen religiösen Organisationen" ('Gatekeepers' and 'Brokers' as 
Interfaces between Religious Organizations). In Alexander-Kenneth Nagel (ed.), Diesseits der Parallelgesellschaft: Neuere Studien zu religiösen Migrantengemeinden in Deutschland (This Side of Parallel Society: New Studies about Religious Migrant Communities in Germany). Bielefeld: transcript. 207-40.

SEIWERT, Hubert. 2003. Popular Religious Movements and Heterodox Sects in Chinese History. Leiden: Brill.

SKOGGARD, Ian A. 1996. The Indigenous Dynamic in Taiwan's Postwar Development: The Religious and Historical Roots of Entrepreneurship. Armonk: Sharpe.

SMEDLEY, Linda N. 1978. The Chinese Community in South Africa. Phase Two: A Sociological Study. Report no. S-50. Pretoria: South African Human Sciences Research Council.

SONG, Arthur. 1995. "Chinese Religion in South Africa." In Martin Prozesky and John D. Gruchy (eds.), Living Faiths in South Africa. London: Hurst. 203-8.

SONG, Guangyu 宋光宇. 1983. 天道鈎沉: 一貫道調查報告 (Tiandao gouchen: Yiguandao diaocha baogao, Exploring the Way of Heaven: Research Report about Yiguandao). Taipei:Yuanyou.

SONG, Guangyu 宋光宇. 1997. “宗教傳播 商業活動與文化認同一貫 道在新加坡的傳播與發展” (Zongjiao chuanbo, shangye huodong yu wenhua rentong: Yiguandao zai Xinjiapo de chuanbo yu fazhan, Religious Propagation, Commercial Activities, and Cultural Identity: The Spread and Development of the Yiguandao in Singapore). Guoli Taiwan daxue wenshizhe xuebao 國立臺灣大學文史哲學報 47:213-58.
SOO, Khin Wah. 1997. "A Study of the Yiguan Dao (Unity Sect) and Its Development in Peninsular Malaysia." PhD dissertation, University of British Columbia.

TWEED, Thomas A. 2006. Crossing and Dwelling: A Theory of Religion. Cambridge, Mass. Harvard University Press.

TWEED, Thomas A. 2015. "Space." In S. Brent Plate (ed.), Key Terms in Material Religion. London: Bloomsbury Academic. 223-30.

$\mathrm{XIAO}$, Xin. 2016. "Comparing Free Chinese Immigration to South Africa in the $20^{\text {th }}$ Century: Survival and Opportunity." Master thesis, University of Cape Town. https://open.uct.ac.za/handle/11427/23781 (accessed on 3 October 2018).

YANG, Hongren 楊弘任. 2015. “綜攝與轉譯一貫道在英國的行動者 網絡分析” (Zongshe yu zhuanyi: Yiguandao zai Yingguo de xingdongzhe wangluo fenxi, Syncretism and Translation: An Actor-Network-Analysis of Yiguandao in England) In Huang Yinggui 黄應貴 (ed.), 日常生活中的當 代宗教 (Richang shenghuo zhong de dangdai zongjiao, Contemporary Religion in Everyday Life). Taipei: Qunxue chubanshe. 235-74.

YAP, Melanie, and Dianne L. MAN. 1996. Colour, Confusion and Concessions: The History of the Chinese in South Africa. Hong Kong: Hong Kong University Press.

ZHHX: Yiguandao zonghui huixun 一貫道總會會訊 (I-Kuan Tao Association General Correspondence). Zhonghe: Zhonghua minguo Yiguandao zonghui, 1991-Present. 